\title{
Sea-ice dynamics strongly promote Snowball Earth initiation and destabilize tropical sea-ice margins
}

\author{
A. Voigt ${ }^{1}$ and D. S. Abbot ${ }^{2}$ \\ ${ }^{1}$ Max Planck Institute for Meteorology, Hamburg, Germany \\ ${ }^{2}$ University of Chicago, Illinois, USA \\ Correspondence to: A. Voigt (aiko.voigt@zmaw.de) \\ Received: 1 June 2012 - Published in Clim. Past Discuss.: 3 July 2012 \\ Revised: 16 November 2012 - Accepted: 20 November 2012 - Published: 21 December 2012
}

\begin{abstract}
The Snowball Earth bifurcation, or runaway icealbedo feedback, is defined for particular boundary conditions by a critical $\mathrm{CO}_{2}$ and a critical sea-ice cover (SI), both of which are essential for evaluating hypotheses related to Neoproterozoic glaciations. Previous work has shown that the Snowball Earth bifurcation, denoted as $\left(\mathrm{CO}_{2}, \mathrm{SI}\right)^{*}$, differs greatly among climate models. Here, we study the effect of bare sea-ice albedo, sea-ice dynamics and ocean heat transport on $\left(\mathrm{CO}_{2}, \mathrm{SI}\right)^{*}$ in the atmosphere-ocean general circulation model ECHAM5/MPI-OM with Marinoan $(\sim 635 \mathrm{Ma})$ continents and solar insolation $(94 \%$ of modern). In its standard setup, ECHAM5/MPI-OM initiates a Snowball Earth much more easily than other climate models at $\left(\mathrm{CO}_{2}, \mathrm{SI}\right)^{*} \approx(500 \mathrm{ppm}, 55 \%)$. Replacing the model's standard bare sea-ice albedo of 0.75 by a much lower value of 0.45 , we find $\left(\mathrm{CO}_{2}, \mathrm{SI}\right)^{*} \approx(204 \mathrm{ppm}, 70 \%)$. This is consistent with previous work and results from net evaporation and local melting near the sea-ice margin. When we additionally disable sea-ice dynamics, we find that the Snowball Earth bifurcation can be pushed even closer to the equator and occurs at a hundred times lower $\mathrm{CO}_{2}:\left(\mathrm{CO}_{2}, \mathrm{SI}\right)^{*} \approx(2 \mathrm{ppm}$, $85 \%)$. Therefore, the simulation of sea-ice dynamics in ECHAM5/MPI-OM is a dominant determinant of its high critical $\mathrm{CO}_{2}$ for Snowball initiation relative to other models. Ocean heat transport has no effect on the critical sea-ice cover and only slightly decreases the critical $\mathrm{CO}_{2}$. For disabled sea-ice dynamics, the state with $85 \%$ sea-ice cover is stabilized by the Jormungand mechanism and shares characteristics with the Jormungand climate states. However, there is no indication of the Jormungand bifurcation and hysteresis in ECHAM5/MPI-OM. The state with $85 \%$ sea-ice cover therefore is a soft Snowball state rather than a true Jor-
\end{abstract}

mungand state. Overall, our results demonstrate that differences in sea-ice dynamics schemes can be at least as important as differences in sea-ice albedo for causing the spread in climate models' estimates of the Snowball Earth bifurcation. A detailed understanding of Snowball Earth initiation therefore requires future research on sea-ice dynamics to determine which model's simulation is most realistic.

\section{Introduction}

The Neoproterozoic glaciations $(\sim 715 \mathrm{Ma}$ and $\sim 635 \mathrm{Ma})$ are characterized by active, wide-spread continental glaciers in the tropics that reached down to sea level (Evans, 2000; Trindade and Macouin, 2007; Macdonald et al., 2010). Building on the runaway ice-albedo feedback (e.g. Budyko, 1969; Sellers, 1969; Marotzke and Botzet, 2007) as well as the geology surrounding these glaciations, Kirschvink (1992) and Hoffman et al. (1998) proposed that Earth might have been in deep freeze with completely ice-covered oceans ${ }^{1}$ during these glaciations. Such climate states have become known as (hard) Snowball Earth.

From a climate dynamics point of view, one of the most important questions concerning the Snowball Earth hypothesis is the location of the bifurcation that is associated with the onset of the runaway ice-albedo feedback (the Snowball Earth bifurcation). The location of the Snowball Earth bifurcation is characterized by a critical sea-ice cover and

\footnotetext{
${ }^{1}$ The sea ice would eventually grow into thick "sea glaciers" that would flow viscously (Goodman and Pierrehumbert, 2003), except potentially in the tropics if a "thin-ice" solution prevailed (McKay, 2000; Pollard and Kasting, 2005).
} 
a critical radiative forcing. The critical sea-ice cover is commonly measured in percent of the global ocean area; the critical radiative forcing is often expressed as the highest atmospheric $\mathrm{CO}_{2}$ at which a Snowball Earth will initiate when starting from a temperate climate with only partial sea-ice cover. In the following, we will denote the location of the Snowball Earth bifurcation as $\left(\mathrm{CO}_{2}, \mathrm{SI}\right)^{*}$.

The critical $\mathrm{CO}_{2}$ is essential for studies attempting to determine the geochemical mechanism for Snowball Earth initiation (e.g., Godderis et al., 2007; Tziperman et al., 2011). Climate models have yielded different estimates for the critical $\mathrm{CO}_{2}$. For example, Chandler and Sohl (2000), using the GISS atmosphere general circulation model coupled to a slab ocean, and Poulsen et al. (2002), using the atmosphere-ocean general circulation model (AOGCM) FOAM, were unable to trigger a Snowball Earth at the insolation and $\mathrm{CO}_{2}$ values they tried, which has sometimes been interpreted as an argument against the Snowball Earth hypothesis (Kennedy et al., 2001; Lubick, 2002; Kerr, 2010). In contrast, the sophisticated AOGCM ECHAM5/MPI-OM initiates a Snowball Earth relatively easily. When run with Marinoan ( $635 \mathrm{Ma}$ ) continents and solar insolation (94\% of modern, $1285 \mathrm{~W} \mathrm{~m}^{-2}$; Gough, 1981), ECHAM5/MPI-OM enters a Snowball Earth when $\mathrm{CO}_{2}$ is decreased to 500 ppm (Fig. 1) $)^{2}$. Interestingly, the equally sophisticated AOGCMs CCSM3 and CCSM4 require $17.5 \mathrm{ppm}$ and $70 \mathrm{ppm} \mathrm{CO}_{2}$, respectively, for Snowball initiation with modern continents and $94 \%$ solar constant (Yang et al., 2012a,b,c). The difference between ECHAM5/MPI-OM and CCSM3/4 is striking, although part of it might be related to differences in the continental configurations (Voigt et al., 2011).

The critical sea-ice cover is important because some physical models for the Neoproterozoic glaciations do not involve complete ice coverage. A basic requirement for consistency with geological evidence is that a model allows active tropical land glaciers flowing into the ocean. The higher the critical sea-ice cover is, the less one needs to invoke completely sea-ice covered oceans to explain the formation of tropical land glaciers. States allowing both tropical land glaciers and significant amounts of open ocean are referred to as soft Snowball Earth states (Hyde et al., 2000; Liu and Peltier, 2010, they are sometimes also called "Slushball" or waterbelt states). Abbot et al. (2011) demonstrated that a particular type of soft Snowball Earth state, the Jormungand state, is possible if the bare sea-ice albedo is low enough. Jormungand states can have stable sea-ice margins at around $10^{\circ} \mathrm{N} / \mathrm{S}$, making conditions for formation of tropical land glaciers extremely favorable, and are separated from warmer

\footnotetext{
${ }^{2}$ Figure 1 contains a simulation with $500 \mathrm{ppm} \mathrm{CO}_{2}$ that was run after Voigt et al. (2011) was published and hence was not included in Voigt et al. (2011).
}

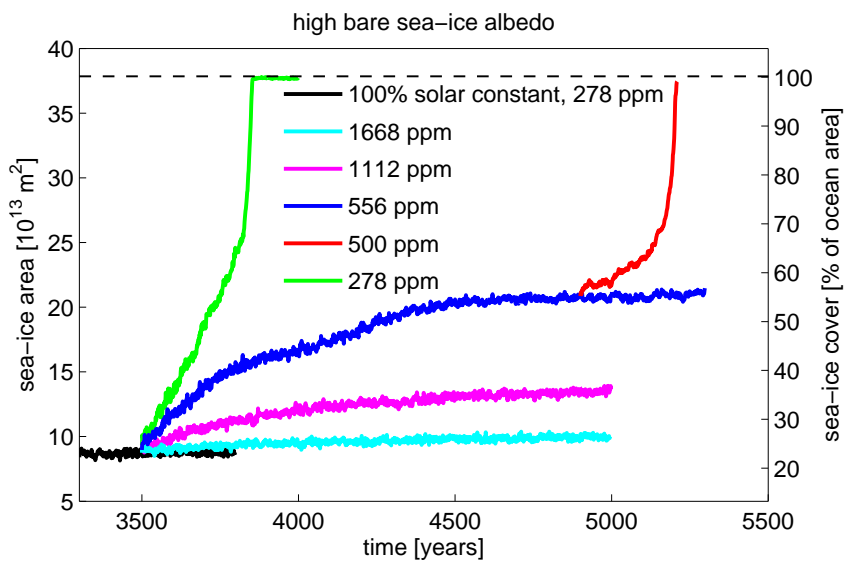

Fig. 1. Initiation of a Marinoan Snowball Earth in ECHAM5/MPIOM with the model's standard high bare sea-ice albedo (Voigt et al., 2011). Sea-ice dynamics and ocean heat transport are fully active. Time evolution of annual-mean global sea-ice cover in response to an abrupt decrease of the solar constant from $100 \%$ to $94 \%$ and a simultaneous increase of atmospheric carbon dioxide. Note that the simulation for $500 \mathrm{ppm} \mathrm{CO}_{2}$ was run after Voigt et al. (2011) was published.

states by an additional bifurcation, making them distinct climate states ${ }^{3}$.

Climate models give varying estimates of the critical seaice cover. For example, ECHAM5/MPI-OM has a critical sea-ice cover of $55 \%$ (measured in per cent of the global ocean area), which appears to be too low to allow tropical land glaciers to co-exist with open tropical ocean because tropical land temperatures remain well above freezing in this state (Voigt et al., 2011; Voigt and Marotzke, 2010). In contrast, CCSM3 has stable climate states with up to $76 \%$ seaice cover, which may be Jormungand states and would likely allow the growth of tropical ice sheets (Yang et al., 2012a,b).

Motivated by the large model spread in $\left(\mathrm{CO}_{2}, \mathrm{SI}\right)^{*}$ we revisit the initiation of a Marinoan Snowball Earth in ECHAM5/MPI-OM. We investigate the sensitivity of Snowball Earth initiation to bare sea-ice albedo, sea-ice dynamics, and ocean heat transport. We quantify the effects of these three factors on $\left(\mathrm{CO}_{2}, \mathrm{SI}\right)^{*}$, which allows us to compare their relative importance for Snowball Earth initiation in ECHAM5/MPI-OM. To our knowledge, this has not yet been done in any climate model, in particular not in a coupled AOGCM, although all three processes have been shown to be important for Snowball Earth initiation.

Decreasing sea-ice albedo weakens the ice-albedo feedback and makes Snowball Earth initiation more difficult (Pierrehumbert et al., 2011; Yang et al., 2012a; Abbot et al., 2011). For snow-covered sea ice, measurements support an

\footnotetext{
${ }^{3}$ Note that all soft Snowball states can have a bifurcation associated with the growth of tropical land glaciers, but a Jormungand state must have a bifurcation associated with the contrast between the albedo of bare and snow-covered sea ice.
} 
albedo of around 0.8 (Brandt et al., 2005; Warren et al., 2002), and most climate models specify this value (Yang et al., 2012a). For bare (snow-free) sea ice, measurements suggest that a low value of 0.45 is more appropriate than the high value of 0.75 used by ECHAM5/MPI-OM. Furthermore, dust on ice may lead to an even lower bare sea-ice albedo in cold, dusty Snowball or near Snowball conditions (Abbot and Pierrehumbert, 2010). CCSM3/4 assume a much lower bare albedo than ECHAM5/MPI-OM, which might explain the models' differences in Snowball Earth initiation. We therefore focus on the effect of a decrease in the bare sea-ice albedo.

Sea-ice dynamics can strongly influence $\left(\mathrm{CO}_{2}, \mathrm{SI}\right)^{*}$ as shown by Lewis et al. $(2003,2007)$ in an ocean general circulation model coupled to an atmospheric energy balance model with prescribed surface winds. However, the results of Lewis et al. $(2003,2007)$ were sensitive to the prescribed surface winds, which prohibited them from determining whether sea-ice dynamics decrease or increase the critical $\mathrm{CO}_{2}$ (Lewis et al., 2007). Moreover, Lewis et al. (2007) did not find stable sea-ice margins equatorward of $60^{\circ} \mathrm{N} / \mathrm{S}$ once they included sea-ice dynamics, which is in sharp contrast to ECHAM5/MPI-OM and CCSM3/4, which simulate stable sea-ice margins at $30^{\circ} \mathrm{N} / \mathrm{S}$ or even lower latitudes despite the fact that they include sea-ice dynamics (Voigt and Marotzke, 2010; Voigt et al., 2011; Yang et al., 2012a,c). Overall, this calls for a detailed investigation of the effect of sea-ice dynamics in coupled AOGCMs that resolve atmospheric dynamics and surface winds. Yang et al. (2012a) found that sea-ice thickness tendencies suggest that sea-ice dynamics lower the critical $\mathrm{CO}_{2}$ in CCSM3. Here, we extend this work by additionally analyzing the sea-ice velocity tendencies and by quantifying the effect of sea-ice dynamics on $\left(\mathrm{CO}_{2}, \mathrm{SI}\right)^{*}$.

Using FOAM, ocean heat transport was identified as a factor that makes Snowball Earth initiation more difficult (Poulsen et al., 2001), especially through the winddriven component of ocean circulation (Poulsen and Jacob, 2004). Consistent with these FOAM results, other coupled AOGCMs showed substantial ocean heat transport towards the sea-ice margin (Voigt and Marotzke, 2010) or even beyond the sea-ice margin to higher latitudes (Yang et al., 2012a,c). From Table 1 of Poulsen and Jacob (2004), one can infer that disabling ocean heat transport leads to a decrease of the critical total solar irradiance (for fixed $\mathrm{CO}_{2}$ ) of at least $2 \%$. Assuming a planetary albedo of 0.3 , this corresponds to a radiative forcing of $4.8 \mathrm{Wm}^{-2}$, which is approximately the radiative forcing associated with a doubling of $\mathrm{CO}_{2}$. In this paper we will rigorously determine the magnitude of the effect of ocean heat transport on the critical $\mathrm{CO}_{2}$ and the critical sea-ice cover in ECHAM5/MPI-OM.

In this contribution, we modify ECHAM5/MPI-OM to investigate the relative importance of bare sea-ice albedo, seaice dynamics and ocean heat transport. To this purpose, we create three new variants of ECHAM5/MPI-OM and determine their $\left(\mathrm{CO}_{2}, \mathrm{SI}\right)^{*}$. First, we decrease the model's bare sea-ice albedo from its high standard value of 0.75 to a low value of 0.45 as used by $\mathrm{CCSM}^{4}$, while keeping the albedo of snow-covered sea ice essentially the same $(\sim 0.80)$. Second, we additionally disable sea-ice dynamics. Third, we additionally disable ocean heat transport by enforcing zero ocean velocities. The latter is only done in combination with disabled sea-ice dynamics in order to separate the effect of ocean heat transport from the effect of ocean drag on sea ice (see Sects. 3 and 5).

For each of the three new variants, our simulations lead to an absolute value for $\left(\mathrm{CO}_{2}, \mathrm{SI}\right)^{*}$. Concerning the critical $\mathrm{CO}_{2}$ our interest is in the relative effect of bare seaice albedo, sea-ice dynamics and ocean heat transport rather than in the absolute $\mathrm{CO}_{2}$ estimate. This is because uncertainties in the boundary conditions (e.g. continental configuration, aerosols, greenhouse gases other than $\mathrm{CO}_{2}$, precise level of solar constant, land surface albedo) and model physics (e.g. precise sea-ice albedo, effect of dust) translate to uncertainty in the absolute $\mathrm{CO}_{2}$. The relative effects should be less sensitive to these uncertainties.

The paper is organized as follows. The atmosphere-ocean general circulation model ECHAM5/MPI-OM, the boundary conditions, and the simulation setup are described in Sect. 2. Section 3 presents the simulations with bare sea-ice albedo decreased to 0.45 , including an analysis of the tendencies of sea-ice thickness and sea-ice velocities. Section 4 describes the simulations with sea-ice dynamics disabled additionally. Ocean heat transport is additionally set to zero in Sect. 5. In Sect. 6, we restart the model from various states with lowlatitude sea-ice margins and increase $\mathrm{CO}_{2}$ to test if any of these states is a Jormungand climate state. A general discussion of our results is given in Sect. 7. The paper closes with conclusions in Sect. 8.

\section{Model and simulation setup}

We use the comprehensive atmosphere-ocean general circulation model ECHAM5/MPI-OM. Apart from a change of the sea-ice albedo, this is the same model that we used to study the initiation of a modern (Voigt and Marotzke, 2010) as well as a Marinoan Snowball Earth (Voigt et al., 2011).

\footnotetext{
${ }^{4}$ Yang et al. (2012a) cite a bare sea-ice albedo of 0.5 for CCSM3, while Pierrehumbert et al. (2011) give 0.45 for the Community Atmosphere Model version 3 (CAM3). CAM3 is the atmospheric component of CCSM3, and uses the same sea-ice albedos as CCSM3. However, because sea-ice albedo is spectrally dependent in CAM3/CCSM3, the cited broadband albedos depend on the assumed partitioning between near-infrared and visible solar radiation at the surface. This, in turn, depends on cloud cover and atmospheric humidity, and is therefore climate dependent. In this study we use the broadband values given in Table 3 of Pierrehumbert et al. (2011), which assume $40 \%$ of solar radiation at the surface is in the visible.
} 


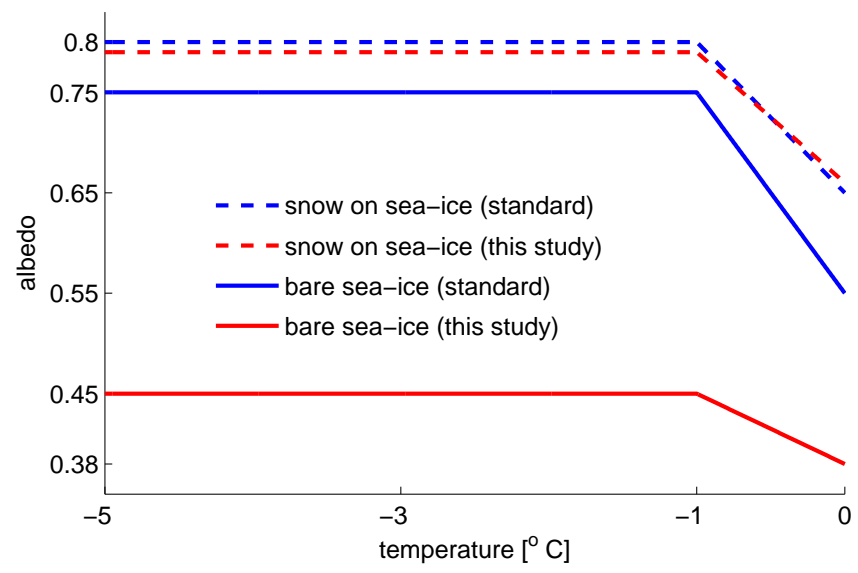

Fig. 2. Albedo of snow on sea ice (dashed) and bare sea ice (solid) of the standard setup of ECHAM5/MPI-OM used in Voigt et al. (2011) and Voigt and Marotzke (2010) (blue) and the values adopted from the Community Atmosphere Model version 3 used in this study (red).

The model is described in detail in Voigt and Marotzke (2010) and Voigt et al. (2011), and references therein.

All simulations use modified albedo values for bare as well as snow-covered sea ice. Instead of the standard seaice albedo of ECHAM5/MPI-OM applied in Voigt et al. (2011) and Voigt and Marotzke (2010), we use the sea-ice albedo of CCSM3 (see footnote 4). Compared to the standard value, the modified bare sea-ice albedo is considerably lower, with a cold albedo of 0.45 instead of 0.75 (for surface temperatures below $-1{ }^{\circ} \mathrm{C}$ ), and a warm albedo of 0.38 instead of 0.55 (for surface temperatures at $0{ }^{\circ} \mathrm{C}$; Fig. 2). The modified albedo of snow-covered sea ice is nearly the same as ECHAM5/MPI-OM's standard value (warm albedo of 0.66 instead of 0.65 , cold albedo of 0.79 instead of 0.8 ; Fig. 2). Therefore, we do not consider the change in snowcovered sea-ice albedo significant. As in the standard setup of ECHAM5/MPI-OM, the snow thickness that separates bare from snow-covered sea ice is $1 \mathrm{~cm}$ water equivalent, which is about 5 times smaller than that used in CCSM $3^{5}$. There is no snow aging or spectral dependence of the sea-ice albedo.

ECHAM5/MPI-OM includes the zero-layer thermodynamic sea-ice model of Semtner (1976) with sea-ice dynamics following Hibler (1979). The sea-ice thermodynamics calculate the local growth and melt of sea ice. Snow on sea ice is explicitly modeled, including snow/sea-ice conversion when the snow/sea-ice interface sinks below sea level because of heavy snow loading. The sea-ice thickness is limited to about $8 \mathrm{~m}$ to avoid dry ocean levels. The sea-ice dy-

\footnotetext{
${ }^{5}$ In ECHAM5/MPI-OM the albedo transition is sudden, whereas in CAM and CCSM3 it is gradual, such that the snow contributes $50 \%$ to the total surface albedo at $2 \mathrm{~cm}$ water equivalent snow thickness, and $90 \%$ at $5 \mathrm{~cm}$ water-equivalent snow thickness (Pierrehumbert et al., 2011).
}

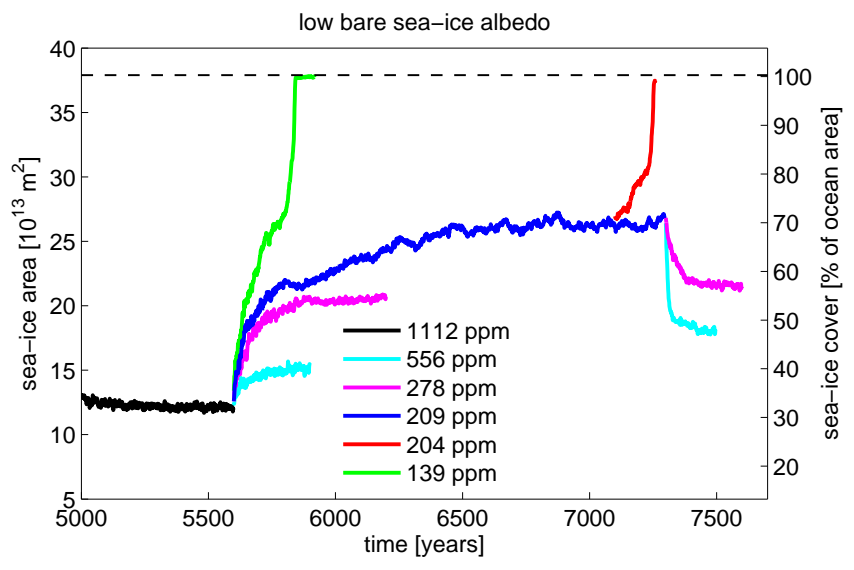

Fig. 3. Simulations with low bare sea-ice albedo. Sea-ice dynamics and ocean heat transport are fully active. Time evolution of annual-mean global sea-ice cover in response to an abrupt change in $\mathrm{CO}_{2}$. The simulation with $1112 \mathrm{ppm} \mathrm{CO}_{2}$ was restarted from the 1112 ppm $\mathrm{CO}_{2}$ simulation with high bare sea-ice albedo (Fig. 1). Also shown are simulations that start from the state with $70 \%$ seaice cover and apply an abrupt increase of $\mathrm{CO}_{2}$ from $209 \mathrm{ppm}$ to various higher levels; these simulations search for the Jormungand bifurcation. All simulations use $94 \%$ solar insolation.

namics scheme transports sea-ice thickness, sea-ice fraction, and snow on sea ice according to the prognosed sea-ice velocities. The sea-ice velocities are calculated based on the stresses of surface winds and ocean currents on sea ice, the Coriolis force, sea-surface tilt, and an assumed sea-ice rheology that describes internal deformation of sea ice. To study the role of sea-ice dynamics for Snowball Earth initiation, we disable sea-ice dynamics in some of the simulations.

Since it is an atmosphere-ocean general circulation model, ECHAM5/MPI-OM simulates the three-dimensional ocean circulation that is consistent with the modeled atmospheric state. The ocean circulation leads to ocean heat transport that can vary over time within a given simulation and differs between the simulations as a consequence of differences in the ocean circulation. For some simulations, we set the ocean heat transport to zero by reducing the ocean model to a single level of $50 \mathrm{~m}$ thickness and enforcing zero ocean velocities. We set ocean heat transport to zero only in combination with disabled sea-ice dynamics. This is necessary to isolate the effect of ocean heat transport from the effect of ocean drag on sea ice. The simulations with zero ocean heat transport apply exactly the same sea-ice thermodynamical scheme as the other simulations.

We specify the same boundary conditions as in Voigt et al. (2011). These are meant to represent the Marinoan period (635 Million years before present) and include low-latitude desert continents with an albedo of 0.272 . We use modern orbital parameters. Non- $\mathrm{CO}_{2}$ well-mixed greenhouse gases are set to their pre-industrial concentrations $\left(\mathrm{CH}_{4}=650 \mathrm{ppb}\right.$, $\mathrm{N}_{2} \mathrm{O}=270 \mathrm{ppb}$, no CFCs). Ozone follows the 1980-1991 

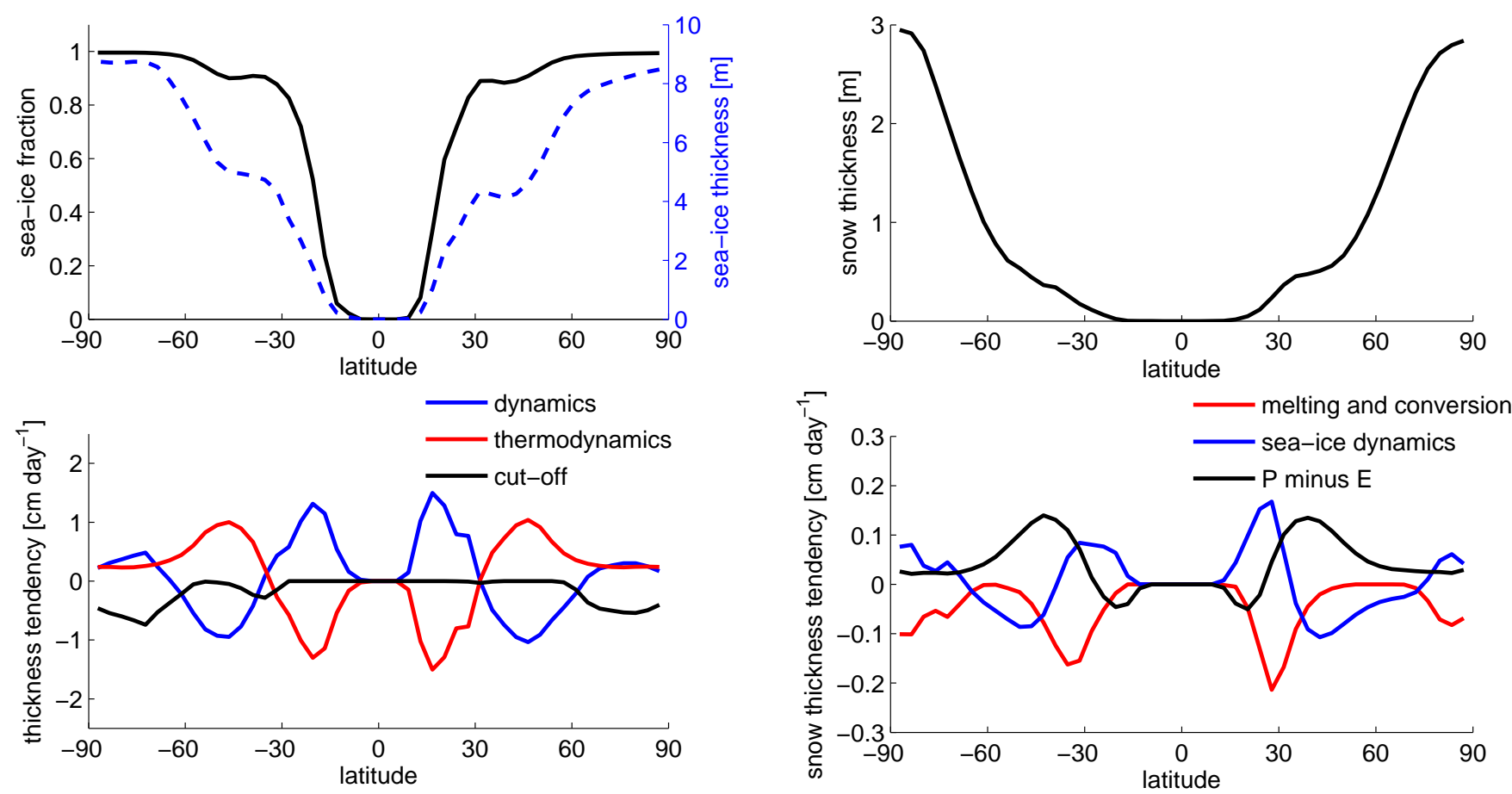

Fig. 4. Simulation with low bare sea-ice albedo and $209 \mathrm{ppm} \mathrm{CO}_{2}$, which results in $70 \%$ sea-ice cover. Top: zonal-mean annual-mean sea-ice fraction (black) and sea-ice thickness (blue). Bottom: zonalmean annual-mean sea-ice thickness tendencies due to sea-ice dynamics (blue), sea-ice thermodynamics (red), and the cut-off of sea ice thicker than $8 \mathrm{~m}$ (black).

climatology of Fortuin and Kelder (1998), aerosols are specified according to Tanré et al. (1984). For a detailed list of the boundary conditions, see Voigt et al. (2011).

All simulations use a Marinoan solar constant of $1285 \mathrm{~W} \mathrm{~m}^{-2}$ (94\% of present-day value; Gough, 1981), while atmospheric $\mathrm{CO}_{2}$ is varied. As in Voigt et al. (2011), we use an atmospheric resolution of spectral truncation $\mathrm{T} 31$ (corresponding to a horizontal grid distance of $3.75^{\circ}$ ) with 19 vertical levels. The ocean model uses 39 vertical levels and a curvilinear grid with horizontal resolution ranging from $50 \mathrm{~km}$ in equatorial regions to $435 \mathrm{~km}$ in parts of the Northern Hemisphere (see Voigt et al., 2011 for further details). All simulations use an atmosphere time step of $2400 \mathrm{~s}$ and an ocean time step of $3600 \mathrm{~s}$.

\section{Decreasing bare sea-ice albedo from 0.75 to 0.45}

In this section we study the sensitivity of Snowball Earth initiation to the albedo of bare, snow-free sea ice. To this purpose we perform simulations in which the bare sea-ice albedo is decreased from the model's high standard value of 0.75 to a low value of 0.45 . Sea-ice dynamics and ocean heat transport are fully active.

Fig. 5. Simulation with low bare sea-ice albedo and $209 \mathrm{ppm}$ $\mathrm{CO}_{2}$, which results in $70 \%$ sea-ice cover. Top: zonal-mean annualmean thickness of snow on sea ice. Bottom: zonal-mean annualmean thickness tendencies for snow on sea ice: local melting and snow/sea-ice conversion (red), sea-ice dynamics (blue), and snowfall minus evaporation over sea ice (black).

We generate a "warm" control simulation for $1112 \mathrm{ppm}$ $\mathrm{CO}_{2}$ by restarting the model from the $1112 \mathrm{ppm} \mathrm{CO}_{2}$ simulation with high bare sea-ice albedo (Fig. 3). For a high bare sea-ice albedo, sea-ice cover equilibrates at around $40 \%$ for $1112 \mathrm{ppm} \mathrm{CO} \mathrm{CO}_{2}$. For $1112 \mathrm{ppm} \mathrm{CO}_{2}$, decreasing the bare seaice albedo thus only marginally affects the sea-ice cover. This is reasonable based on the fact that sea ice is restricted to latitudes poleward of $40^{\circ} \mathrm{N} / \mathrm{S}$, where it is snow-covered yearround except near the sea-ice margin during local summer.

Starting from $1112 \mathrm{ppm} \mathrm{CO}_{2}$, we abruptly decrease $\mathrm{CO}_{2}$ to determine $\left(\mathrm{CO}_{2}, \mathrm{SI}\right)^{*}$ (Fig. 3). In contrast to simulations with high bare sea-ice albedo, a decrease of $\mathrm{CO}_{2}$ to preindustrial levels (278 ppm) does not trigger a Snowball Earth. For 209 ppm, sea-ice cover equilibrates at $70 \%$, but a small further decrease of $\mathrm{CO}_{2}$ to $204 \mathrm{ppm}$ pitches the model into a Snowball state. Therefore, decreasing the bare sea-ice albedo from 0.75 to 0.45 allows stable states with $70 \%$ seaice cover instead of $55 \%$ and lowers the critical $\mathrm{CO}_{2}$ by a factor of 2.5 from 500 to $205 \mathrm{ppm}$. However, even with low bare sea-ice albedo, ECHAM5/MPI-OM still enters a Snowball Earth more easily than the AOGCMs CCSM3/4 (Yang et al., 2012a,b,c) and FOAM (Poulsen and Jacob, 2004), although comparing the models is somewhat hampered by differences in the continental configurations. For example, 


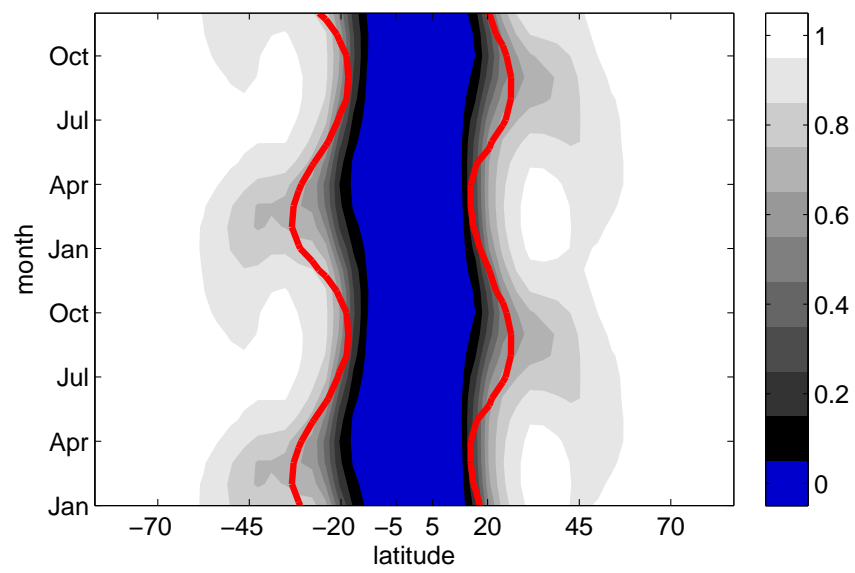

Fig. 6. Simulation with low bare sea-ice albedo and $209 \mathrm{ppm} \mathrm{CO}_{2}$, which results in $70 \%$ sea-ice cover. Annual cycle of zonal-mean sea-ice fraction. Blue indicates open ocean, white a sea-ice fraction of one (see color bar). Poleward of the red line, sea ice is snowcovered and hence highly reflective. Equatorward of the red line, sea ice is bare and hence comparably dark.

given that the low-latitude Marinoan continents cool the climate through redistribution of bright land from high to low latitude (Voigt et al., 2011), part of the much lower critical $\mathrm{CO}_{2}$ in CCSM3 and CCSM4 might be due to use of modern continents.

Sea-ice dynamics offer a potential explanation for why the strong decrease in the bare sea-ice albedo has an only modest effect on Snowball Earth initiation in ECHAM5/MPI$\mathrm{OM}$. We diagnose the dynamical and thermodynamical seaice thickness tendencies in the simulation with $70 \%$ seaice cover $(209 \mathrm{ppm} \mathrm{CO} 2)$. In the subtropics, sea-ice dynamics generate positive thickness tendencies that in the annual and zonal-mean are as large as $1.5 \mathrm{~cm} \mathrm{day}^{-1}$ at around $20^{\circ} \mathrm{N} / \mathrm{S}$ (Fig. 4) and are balanced by thermodynamical melting. In mid-latitudes, the role of sea-ice dynamics and thermodynamics are reversed, with sea ice growing by thermodynamics and being transported out of the mid-latitudes into the subtropics by sea-ice dynamics. The pattern of seaice transport from mid- to low-latitudes is consistent with what Yang et al. (2012a) found in CCSM3, although subtropical tendencies are twice as large in ECHAM5/MPIOM. In polar latitudes, artificial cut-off of sea ice thicker than $8 \mathrm{~m}$ becomes substantial. This likely explains the difference in the polar dynamical thickness tendencies between ECHAM5/MPI-OM and CCSM3 as the latter does not restrict sea-ice thickness.

Given a sea-ice density of $910 \mathrm{~kg} \mathrm{~m}^{-3}$ and a sea-ice melting enthalpy of $330 \times 10^{3} \mathrm{~J} \mathrm{~kg}^{-1}$, a sea-ice thickness tendency of $1 \mathrm{~cm} \mathrm{day}^{-1}$ corresponds to a surface cooling of $35 \mathrm{~W} \mathrm{~m}^{-2}$. Sea-ice dynamics therefore strongly cool latitudes equatorward of $30^{\circ} \mathrm{N} / \mathrm{S}$.

This cooling is further supported by associated equatorward transport of snow on sea ice, which has a much higher albedo than bare sea ice (Fig. 5). In mid-latitudes snow fall exceeds evaporation over sea ice, so mid-latitude sea ice is covered by snow at least $0.1 \mathrm{~m}$ thick (Fig. 5). In low-latitudes, the snow gained through transport is balanced by a combination of snow melt and net evaporation. The net evaporation reflects the subsiding branches of the Hadley cell and is a sign of the Jormungand mechanism of Abbot et al. (2011). However, due to the substantial snow transport, sea ice is not generally bare in low latitudes. Indeed, the latitude that separates snow-covered from bare sea ice shows a strong seasonal migration: low-latitude sea ice is snow-covered during winter and spring but bare during summer and fall (Fig. 6). This migration mainly results from the seasonal cycle of the local snow melt, with strong melting in summer and fall and no melting in winter and spring, whereas sea-ice dynamics transport snow equatorward during all seasons.

We now analyze the time-mean zonal and meridional seaice velocity balance to determine which processes drive the equatorward sea-ice transport. In ECHAM5/MPI-OM, advection of sea-ice velocity is neglected (Marsland et al., 2003), so the balance comprises velocity tendencies due to the Coriolis force, wind and ocean stresses, sea-level tilt, and interaction between floes due to, e.g. cracking, rifting and deformation. The flow interaction is described by the seaice rheology (Feltham, 2008), which in the viscous-plastic assumption of Hibler (1979) is the sum of the gradient of the ice pressure and additional internal forces. The velocity balances read:

$$
\begin{gathered}
\frac{\partial u_{\text {ice }}}{\partial t}=0=f v_{\text {ice }}+\frac{1}{m_{\text {ice }}}\left(\tau_{\mathrm{a}}^{u}+\tau_{\mathrm{o}}^{u}\right)-\frac{g}{r \cos \theta} \frac{\partial H}{\partial \lambda} \\
-\frac{1}{2 m_{\text {ice }} r \cos \theta} \frac{\partial P}{\partial \lambda}+\frac{1}{m_{\text {ice }}} F^{u} \\
\frac{\partial v_{\text {ice }}}{\partial t}=0=-f u_{\text {ice }}+\frac{1}{m_{\text {ice }}}\left(\tau_{\mathrm{a}}^{v}+\tau_{\mathrm{o}}^{v}\right) \\
-\frac{g}{r} \frac{\partial H}{\partial \theta}-\frac{1}{2 m_{\text {ice }} r} \frac{\partial P}{\partial \theta}+\frac{1}{m_{\text {ice }}} F^{v} .
\end{gathered}
$$

Here, $u_{\text {ice }}$ and $v_{\text {ice }}$ are the zonal and meridional sea-ice velocity, $f$ is the Coriolis parameter, $m_{\text {ice }}$ is the combined seaice and snow mass per unit area, $\tau_{\mathrm{a}}$ and $\tau_{\mathrm{o}}$ are the wind and ocean stresses on sea ice, $g$ is Earth's gravitational acceleration, $r$ is the radius of Earth, $H$ is sea-surface height, $P$ denotes the ice pressure, and $F$ denotes additional internal forces given by the sea-ice rheology. The wind and ocean stresses result from the $10 \mathrm{~m}$ wind, $\left(u_{10}, v_{10}\right)$, and the surface ocean velocity, $\left(u_{o}, v_{o}\right)$ :

$\left(\tau_{\mathrm{a}}^{u}, \tau_{\mathrm{a}}^{v}\right)=\rho_{\mathrm{a}} C_{\mathrm{a}}\left|\left(u_{10}, v_{10}\right)\right|\left(u_{10}, v_{10}\right)$,

$\left(\tau_{\mathrm{w}}^{u}, \tau_{\mathrm{w}}^{v}\right)=\rho_{\mathrm{w}} C_{\mathrm{w}}\left|\left(u_{\mathrm{o}}-u_{\text {ice }}, v_{\mathrm{o}}-v_{\text {ice }}\right)\right|\left(u_{o}-u_{\text {ice }}, v_{\mathrm{o}}-v_{\text {ice }}\right)$.

$C_{\mathrm{a}}$ and $C_{\mathrm{o}}$ are the unitless atmosphere and ocean drag coefficients; $\rho_{\mathrm{a}}$ and $\rho_{\mathrm{w}}$ the density of air and water. No turning angles are applied. The ice pressure describes the viscous flow of thicker sea ice towards thinner sea ice through

$P=P^{*} h_{\text {ice }} \exp \left(-C^{*}\left(1-c_{\text {ice }}\right)\right)$, 

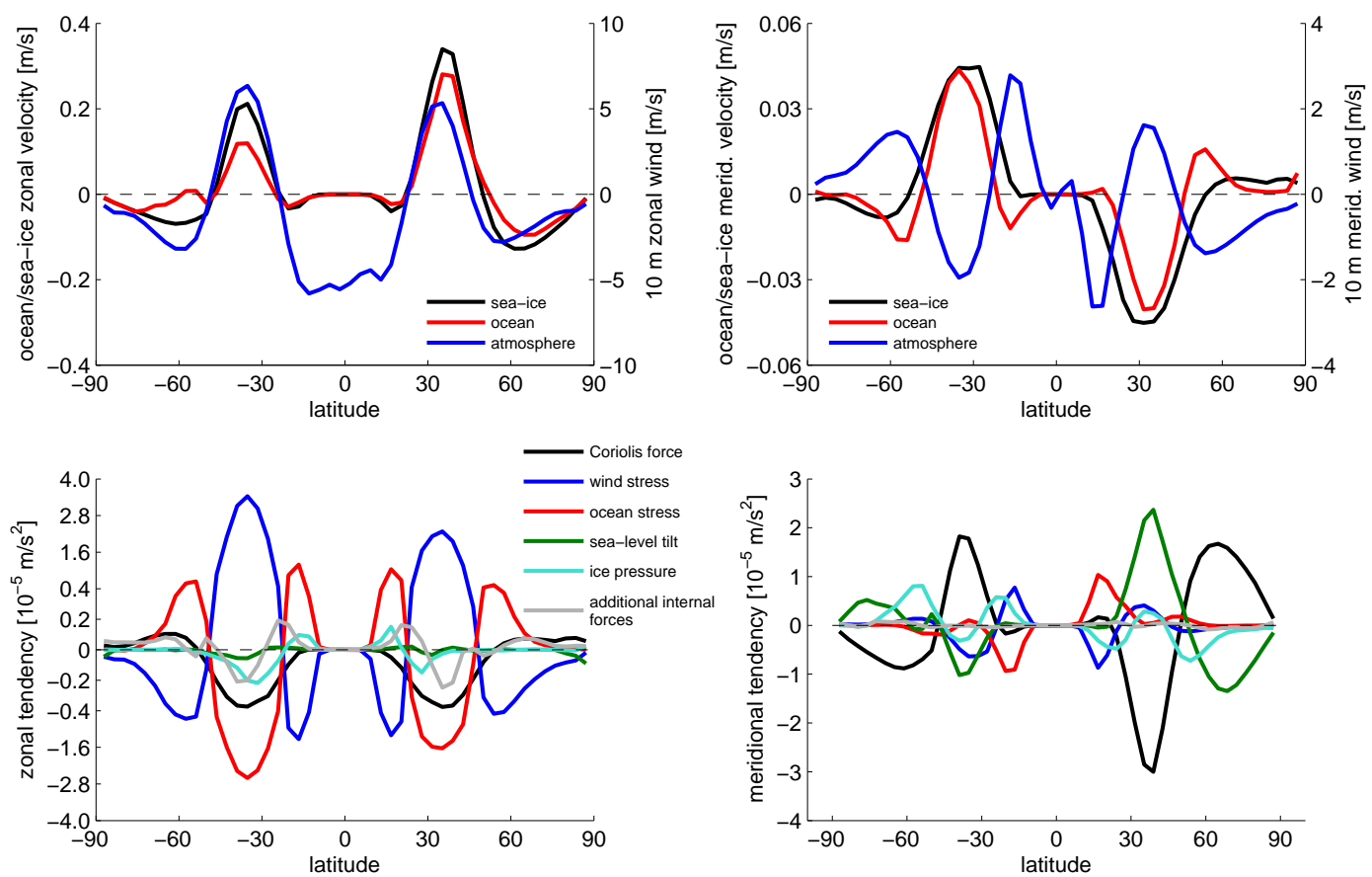

Fig. 7. Analysis of sea-ice velocity tendencies in the $\mathrm{CO}_{2}=209 \mathrm{ppm}$ simulation with low bare sea-ice albedo and fully active sea-ice and ocean dynamics. The simulation equilibrates at $70 \%$ sea-ice cover. Top row: zonal (left) and meridional (right) velocities of sea ice (black), the surface ocean layer (red), and the $10 \mathrm{~m}$ wind. For the ocean velocities only sea-ice points are taken into account, which leads to the zero values near the equator. The left y-axis is for the sea-ice/ocean velocities, the right y-axis for the $10 \mathrm{~m}$ wind. Bottom row: zonal (left) and meridional (right) sea-ice velocity tendencies. Note that for the zonal sea-ice velocity tendencies, the y-axis has a non-linear scaling.

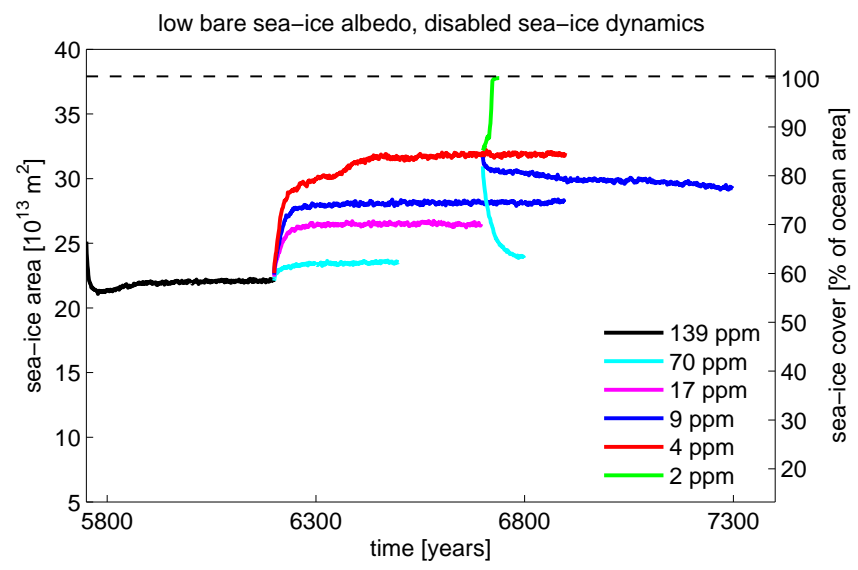

Fig. 8. Simulations with low bare sea-ice albedo and disabled seaice dynamics. Ocean heat transport is fully active. Evolution of annual-mean global sea-ice cover in response to an abrupt change

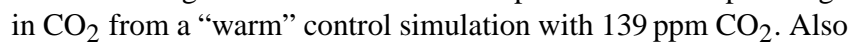
shown are simulations that start from the state with $85 \%$ sea-ice cover and apply an abrupt increase of $\mathrm{CO}_{2}$ from $4 \mathrm{ppm}$ to various higher levels; these simulations search for the Jormungand bifurcation. All simulations use $94 \%$ solar insolation. with sea-ice concentration $c_{\text {ice }}$, sea-ice thickness $h_{\text {ice }}$, and positive empirical parameters $P^{*}$ and $C^{*}$. In the version of ECHAM5/MPI-OM that we use, $P^{*}=40 \cdot 10^{3} \mathrm{Nm}^{-2}$ and $C^{*}=20$. These values are in the range of values usually applied in sea-ice dynamical models (Feltham, 2008; Losch et al., 2010).

Figure 7 shows the sea-ice velocity tendencies together with the sea-ice velocity itself, the $10 \mathrm{~m}$ wind and the surface ocean velocity for the simulation with $70 \%$ sea-ice cover $\left(209 \mathrm{ppm} \mathrm{CO} \mathrm{CO}_{2}\right.$ ). At $35^{\circ} \mathrm{N} / \mathrm{S}$ there is a strong eastward sea-ice "jet" that is driven by eastward surface winds from the Ferrell cell. The zonal velocity balance shows that this eastward wind is mainly balanced by ocean stresses and the Coriolis force. The latter is negative because sea ice moves towards the equator. Closer to the sea-ice margin, that is equatorward of $25^{\circ} \mathrm{N} / \mathrm{S}$, the trade winds of the Hadley circulation cause westward zonal wind stress. If sea-ice motion were in Ekman balance with the wind stress, one would expect poleward sea-ice motion there. However, Ekman balance does not hold there even qualitatively, and strong eastward zonal ocean stress and tendencies of the ice pressure and internal forces overcompensate the westward wind stress. As a result, sea ice continues to move equatorward.

To understand what drives the equatorward sea-ice motion close to the sea-ice margin, we turn to the meridional velocity tendencies. Equatorward surface winds from the Hadley 

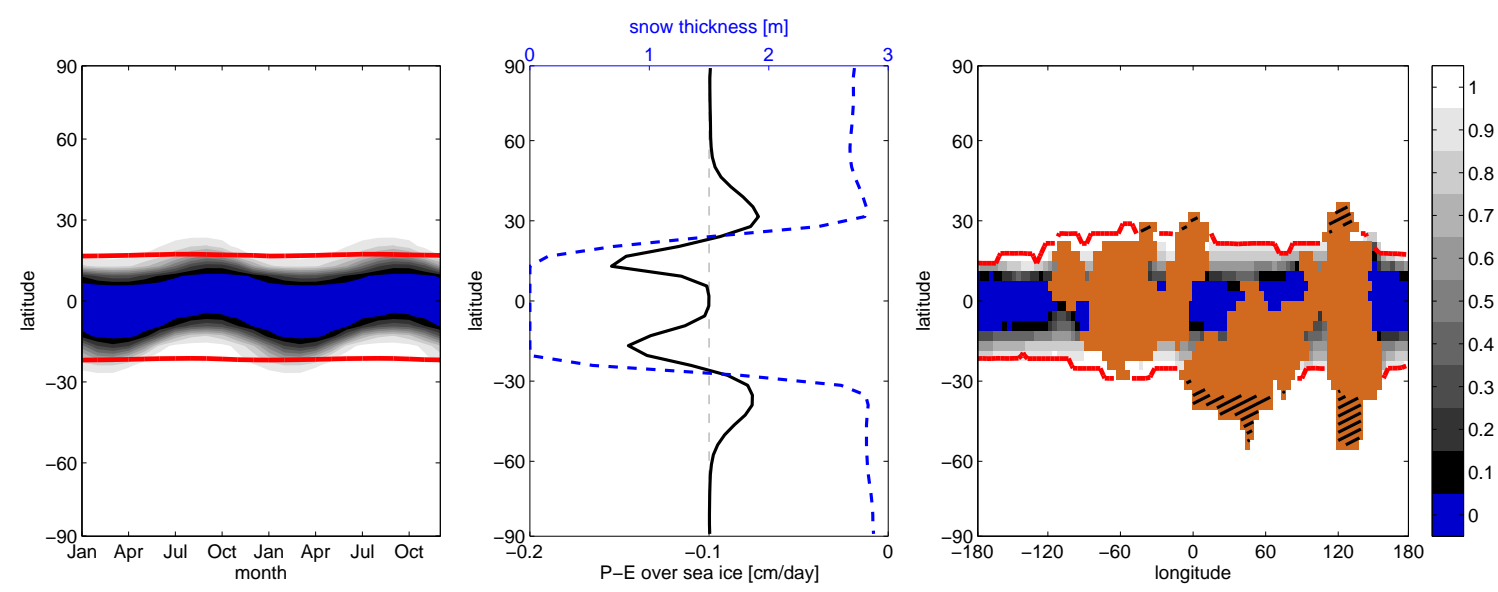

Fig. 9. Simulation with low bare sea-ice albedo, disabled sea-ice dynamics, and $4 \mathrm{ppm} \mathrm{CO}_{2}$. The simulation equilibrates at $85 \%$ sea-ice cover. Left: seasonal cycle of zonal-mean sea-ice fraction. Blue indicates open ocean, white a sea-ice fraction of one (see color bar on the right). The red line separates bare sea ice (equatorward of the red line) from snow-covered sea ice (poleward of the red line). Middle: Annualmean zonal-mean snow fall onto sea ice minus evaporation over sea ice (black solid) and thickness of snow on sea ice (blue dashed). Right: annual-mean sea-ice fraction with the same color coding as in the left figure. The red line separates bare sea ice (equatorward of the red line) from snow-covered sea ice (poleward of the red line). Continents are shown in brown. In the hatched continental regions snow accumulation exceeds $1 \mathrm{cmyr}^{-1}$.

circulation are the main driver, and are supported by the equatorward ice pressure that results from the meridional gradient in sea-ice thickness. In contrast, sea ice experiences strong poleward ocean drag. Part of this drag results from poleward surface ocean currents, which are a consequence of the wind-driven subtropical ocean cells generated by the Hadley circulation. In summary, we find that close to the seaice margin, the equatorward sea-ice motion results mainly from equatorward wind stress of the Hadley circulation. Viscous flow supports the equatorward sea-ice motion, while ocean drag works against it.

\section{Disabling sea-ice dynamics}

The previous section has shown that sea-ice dynamics cause strong transport of sea ice and snow from mid- to lowlatitudes. This suggests that sea-ice dynamics promote Snowball initiation and destabilize low-latitude sea-ice margins. In this section we test this hypothesis by performing simulations with disabled sea-ice dynamics. As in the previous section, these simulations use the low bare sea-ice albedo.

Figure 8 shows the time-evolution of sea-ice cover when sea-ice dynamics are disabled. The $139 \mathrm{ppm}$ simulation starts from the $139 \mathrm{ppm}$ simulation with low bare sea-ice albedo and active sea-ice dynamics. Without sea-ice dynamics, Snowball Earth initiation requires a decrease of $\mathrm{CO}_{2}$ to $2 \mathrm{ppm}$. Disabling sea-ice dynamics hence lowers the critical $\mathrm{CO}_{2}$ by a factor of 100 from 205 to $2 \mathrm{ppm}$, in line with the intuition built from the analysis of the sea-ice thickness and snow on sea-ice tendencies in Sect. 3.
Disabling sea-ice dynamics also shifts the runaway icealbedo feedback to higher sea-ice cover and allows us to find a state with a stable sea-ice margin very close to the Equator. For $4 \mathrm{ppm} \mathrm{CO}_{2}$, sea-ice cover equilibrates at $85 \%$, corresponding to an annual-mean sea-ice margin at $10^{\circ} \mathrm{N} / \mathrm{S}$. (Fig. 9, right). During all months, sea ice poleward of $20^{\circ} \mathrm{N} / \mathrm{S}$ is covered by thick snow and has a high albedo, while sea ice equatorward of $20^{\circ} \mathrm{N} / \mathrm{S}$ is snow-free and has a low albedo. The low albedo of the bare sea ice weakens the ice-albedo feedback in low latitudes and allows the sea-ice margin to stabilize in the tropics. However, we emphasize that this tropical sea-ice margin is only possible in ECHAM5/MPI-OM when sea-ice dynamics and the associated equatorward transport of sea ice and snow are disabled.

The separation of snow-covered from bare sea ice at $20^{\circ} \mathrm{N} / \mathrm{S}$ is a consequence of the atmospheric hydrological cycle. Poleward of $20^{\circ} \mathrm{N} / \mathrm{S}$ there is net accumulation of snow on sea ice, while evaporation over sea ice exceeds snow fall equatorward of $20^{\circ} \mathrm{N} / \mathrm{S}$ (Fig. 9, middle). This hydrological pattern is consistent with the mean meridional circulation of the atmosphere. In particular, the subsiding branches of the Hadley cell are zones of net evaporation, which explains the jump in snow thickness and sea-ice albedo at $20^{\circ} \mathrm{N} / \mathrm{S}$. This confirms that the Jormungand mechanism of Abbot et al. (2011) can create constantly bare low-latitude sea ice not only in aquaplanet simulations without ocean heat transport but also in the coupled AOGCM ECHAM5/MPI-OM with realistic continents, albeit only when sea-ice dynamics are disabled.

With the tropical sea-ice margin at $10^{\circ} \mathrm{N} / \mathrm{S}$, snow continuously accumulates on the continental regions around $30^{\circ} \mathrm{N}$ and $40^{\circ} \mathrm{S}$ (Fig. 9, right). Annual-mean land temperatures are 
at or below $0{ }^{\circ} \mathrm{C}$ even at the equator, despite the uniform low continental elevation of $100 \mathrm{~m}$. This suggests that with such a tropical sea-ice margin, tropical land glacier formation would be easy.

\section{Disabling ocean heat transport}

Coupled AOGCM studies have suggested that by converging heat to the sea-ice margin, ocean dynamics work against Snowball Earth initiation and stabilize the sea-ice margin (Poulsen and Jacob, 2004; Voigt and Marotzke, 2010; Ferreira et al., 2011; Yang et al., 2012b). Consistent with this, we find about $10 \mathrm{~W} \mathrm{~m}^{-2}$ convergence of ocean heat transport at the sea-ice margin in the $4 \mathrm{ppm}$ simulation of the previous section (Fig. 10). The ocean heat transport results from shallow and narrow wind-driven ocean cells with a strength of about $150 \mathrm{~Sv}$. This raises the question of to what extent ocean heat transport influences the critical $\mathrm{CO}_{2}$ and if ocean heat transport is crucial for the stability of the tropical, $10^{\circ} \mathrm{N} / \mathrm{S}$ sea-ice margin.

In this section we show results from ECHAM5/MPI-OM when we disable ocean heat transport by reducing the ocean model to one level of $50 \mathrm{~m}$ thickness and enforcing zero ocean velocities. All simulations use the low bare sea-ice albedo of 0.45 . Ocean velocities not only transport heat but also exert drag on sea ice (see Sect. 3). All simulation therefore use disabled sea-ice dynamics such that we truly measure the effect of ocean heat transport alone. In essence, this variant of ECHAM5/MPI-OM is an atmospheric general circulation model coupled to a mixed-layer ocean with zero ocean heat transport but with exactly the same sea-ice thermodynamics as the full ECHAM5/MPI-OM model. The latter implies that it allows fractionally sea-ice covered grid boxes and tracks snow on sea ice, which is not the case for the stand-alone ECHAM5 mixed-layer ocean setup used in Abbot et al. (2011).

Figure 11 presents time-series of sea-ice cover for the simulations with disabled ocean heat transport. Comparing these simulations to those with ocean heat transport at the same $\mathrm{CO}_{2}$ level, we find that setting ocean heat transport to zero cools the climate and leads to a $10 \%$ increase in sea-ice cover. For disabled ocean heat transport, Snowball initiation requires a decrease of $\mathrm{CO}_{2}$ to $4 \mathrm{ppm}$ instead of $2 \mathrm{ppm}$ for active ocean heat transport. In agreement with previous studies, ocean heat transport therefore suppresses the tendency to initiate a Snowball. However, sea-ice dynamics decrease the critical $\mathrm{CO}_{2}$ far more than the ocean heat transport increases it. The relatively small effect of ocean heat transport is surprising but is consistent with results from the FOAM model (see Sect. 1).

Ocean heat transport has no effect on the critical seaice cover in ECHAM5/MPI-OM. Decreasing $\mathrm{CO}_{2}$ to $9 \mathrm{ppm}$ leads to a stable state with $85 \%$ sea-ice cover, corresponding to a tropical sea-ice margin at $10^{\circ} \mathrm{N} / \mathrm{S}$. The distributions

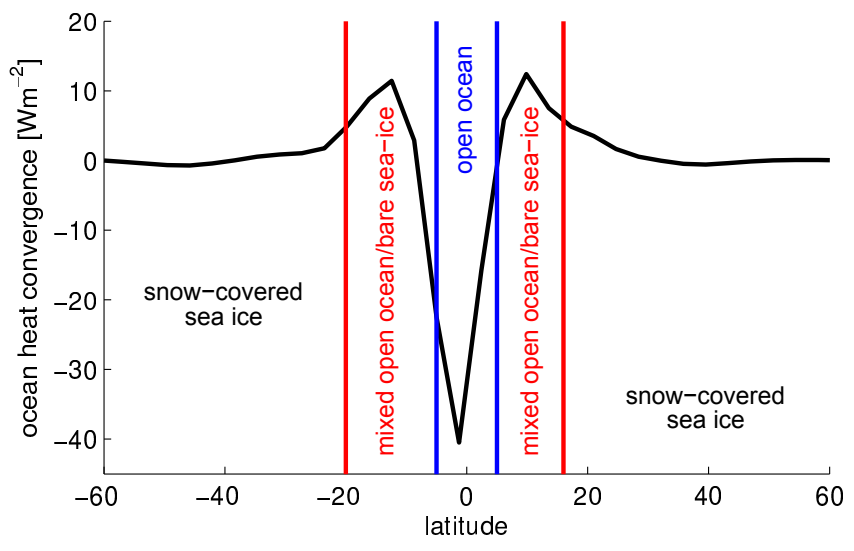

Fig. 10. Convergence of ocean heat transport for the $4 \mathrm{ppm} \mathrm{CO}_{2}$ simulation with low bare sea-ice albedo and disabled sea-ice dynamics. The simulation equilibrates at $85 \%$ sea-ice cover. The blue lines separate the year-round open ocean area from areas with seasonal bare sea ice. The red lines indicate the border between areas with seasonal bare sea ice and areas with year-round snow-covered sea ice (cf. Fig. 9 left).

of sea ice, snow on sea ice, accumulation of snow on land, and the hydrological pattern of this state closely resemble the $4 \mathrm{ppm}$ simulation with disabled sea-ice dynamics but active ocean heat transport (Fig. 9). This demonstrates that the tropical, $10^{\circ} \mathrm{N} / \mathrm{S}$ sea-ice margin is ultimately stabilized by the low bare sea-ice albedo and not by the convergence of ocean heat transport.

\section{The state with tropical sea-ice margin at $10^{\circ} \mathrm{N} / \mathrm{S}$ is a soft Snowball Earth state rather than a Jormungand state}

When we disable sea-ice dynamics we find a state with $85 \%$ sea-ice cover and a tropical sea-ice margin at $10^{\circ} \mathrm{N} / \mathrm{S}$. This state has properties characteristic of the Jormungand states of Abbot et al. (2011). In particular, the sea-ice margin is very close to the equator, traces a serpent-like shape during the course of the year, and sea ice equatorward of $20^{\circ} \mathrm{N} / \mathrm{S}$ is bare year-round while sea ice poleward of $20^{\circ} \mathrm{N} / \mathrm{S}$ is constantly covered by thick snow (Fig. 9, left).

These properties suggest that the state with $85 \%$ sea-ice cover might be a Jormungand state. If it were, then it would be separated from states with less sea-ice cover by the Jormungand bifurcation and associated hysteresis. Put differently, when starting from the state with $85 \%$ sea-ice cover and increasing $\mathrm{CO}_{2}$, sea-ice cover would stay close to $85 \%$ and would not retreat to the sea-ice cover that we find when approaching that $\mathrm{CO}_{2}$ level from a warmer simulation with higher $\mathrm{CO}_{2}$.

We start with increasing $\mathrm{CO}_{2}$ in simulations with disabled sea-ice dynamics but active ocean heat transport. When $\mathrm{CO}_{2}$ is increased from 4 to $9 \mathrm{ppm}$, sea-ice cover does not stay 


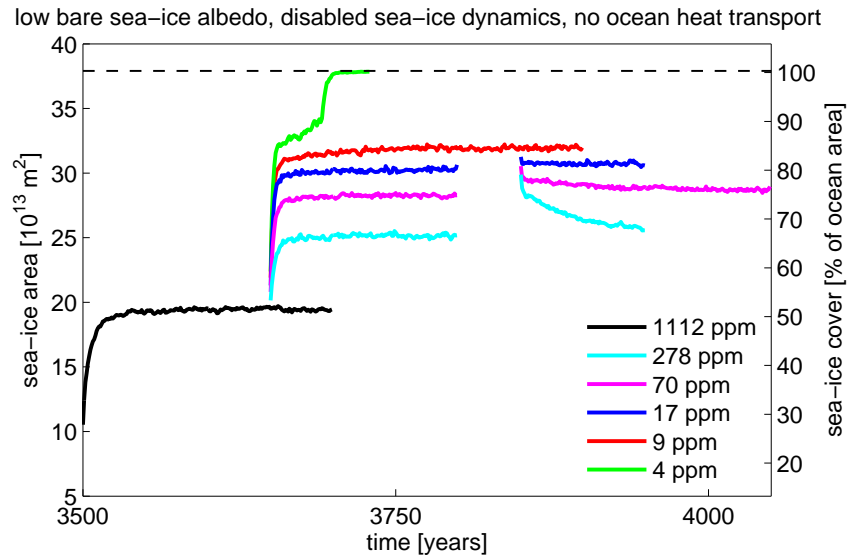

Fig. 11. Simulations with low bare sea-ice albedo, disabled sea-ice dynamics, and disabled ocean heat transport. Evolution of annualmean global sea-ice cover in response to an abrupt change in $\mathrm{CO}_{2}$ from a "warm" control simulation with $1112 \mathrm{ppm} \mathrm{CO}_{2}$. Also shown are simulations that start from the state with $85 \%$ sea-ice cover and apply an abrupt increase of $\mathrm{CO}_{2}$ from $9 \mathrm{ppm}$ to various higher levels; these simulations search for the Jormungand bifurcation. All simulations use $94 \%$ solar insolation.

close to $85 \%$ but decreases to $78 \%$ within $600 \mathrm{yr}$, with no indication that the decrease in sea-ice cover during the last $100 \mathrm{yr}$ is slower than during the first $100 \mathrm{yr}$ (Fig. 8). Similarly, when $\mathrm{CO}_{2}$ is increased to $70 \mathrm{ppm}$, sea-ice cover shrinks quickly to $60 \%$. The lack of hysteresis indicates that the state with $85 \%$ sea-ice cover is not separated from states with less sea-ice cover by a Jormungand bifurcation. This implies that the state with $85 \%$ sea-ice cover belongs to the same equilibrium branch as the states with less sea-ice cover and is not a true Jormungand state. However, it should still be considered a soft Snowball state because land glaciers can likely form in this state given the substantial accumulation of snow on land (Fig. 9, right).

Ocean heat transport is not responsible for the lack of Jormungand hysteresis. To show this, we run analogous simulations with disabled sea-ice dynamics and disabled ocean heat transport. When $\mathrm{CO}_{2}$ is increased from $9 \mathrm{ppm}$ to 17,70 , and $278 \mathrm{ppm}$, there is no sign for hysteresis.

Finally, we find no sign of hysteresis in simulations with active sea-ice dynamics and active ocean heat transport (Fig. 3). Overall, none of the three variants of ECHAM5/MPI-OM exhibits the Jormungand bifurcation found in Abbot et al. (2011). The two variants with disabled sea-ice dynamics exhibit states that have their sea-ice margin in the tropics at $10^{\circ} \mathrm{N} / \mathrm{S}$ and share characteristics of the Jormungand states, but these states should be considered soft Snowball Earth states.

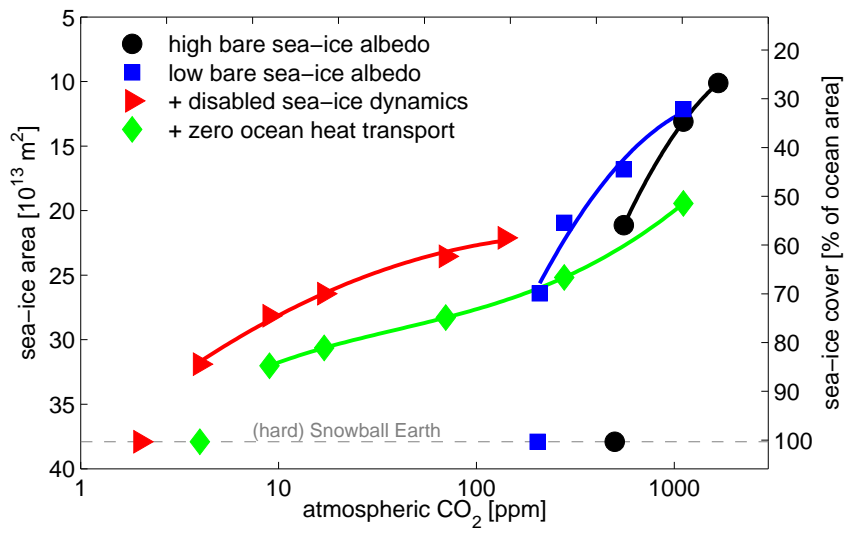

Fig. 12. Sea-ice cover as a function of $\mathrm{CO}_{2}$ for simulations with high bare sea-ice albedo (black circles; Voigt et al., 2011), simulations with low bare sea-ice albedo (blue squares), simulations with low bare sea-ice albedo and disabled sea-ice dynamics (red triangles), and simulations with low bare sea-ice albedo, disabled sea-ice dynamics and disabled ocean heat transport (green diamonds). All simulations use $94 \%$ solar insolation. The lines are mainly drawn to guide the eye but also indicate that the simulations belong to the same equilibrium branch.

\section{Discussion}

In this contribution, we revisit Marinoan Snowball Earth initiation in the comprehensive atmosphere-ocean general circulation model ECHAM5/MPI-OM. To this end, we create three new variants of the model by successively decreasing the albedo of bare sea ice from the model's high standard value of 0.75 to a low value of 0.45 , disabling sea-ice dynamics and finally disabling ocean heat transport. For all three variants we determine the Snowball Earth bifurcation point, which, in conjunction with Voigt et al. (2011), allows us to quantify the sensitivity of the critical $\mathrm{CO}_{2}$ and sea-ice cover to bare sea-ice albedo, sea-ice dynamics, and ocean heat transport. Figure 12 summarizes our results.

Regarding the critical $\mathrm{CO}_{2}$, our results are in qualitative agreement with previous studies. A lower bare sea-ice albedo (Pierrehumbert et al., 2011; Yang et al., 2012a) and ocean heat transport (Poulsen et al., 2001; Poulsen and Jacob, 2004) make Snowball Earth initiation more difficult, while seaice dynamics promote Snowball Earth initiation by equatorward sea-ice transport (Yang et al., 2012a). We have shown that in ECHAM5/MPI-OM sea-ice dynamics have by far the largest influence as they change the critical $\mathrm{CO}_{2}$ by a factor of 100 while large changes in the bare sea-ice albedo and ocean heat transport only modify it by about a factor of two. Even for a low bare sea-ice albedo of 0.45 , the critical $\mathrm{CO}_{2}$ in ECHAM5/MPI-OM is still higher than in CCSM3/4 and FOAM, so the difference among the models cannot be mainly attributed to sea-ice albedo. In contrast, ECHAM5/MPI-OM has an extremely low critical $\mathrm{CO}_{2}$ when sea-ice dynamics are neglected. This demonstrates that sea-ice dynamics are 


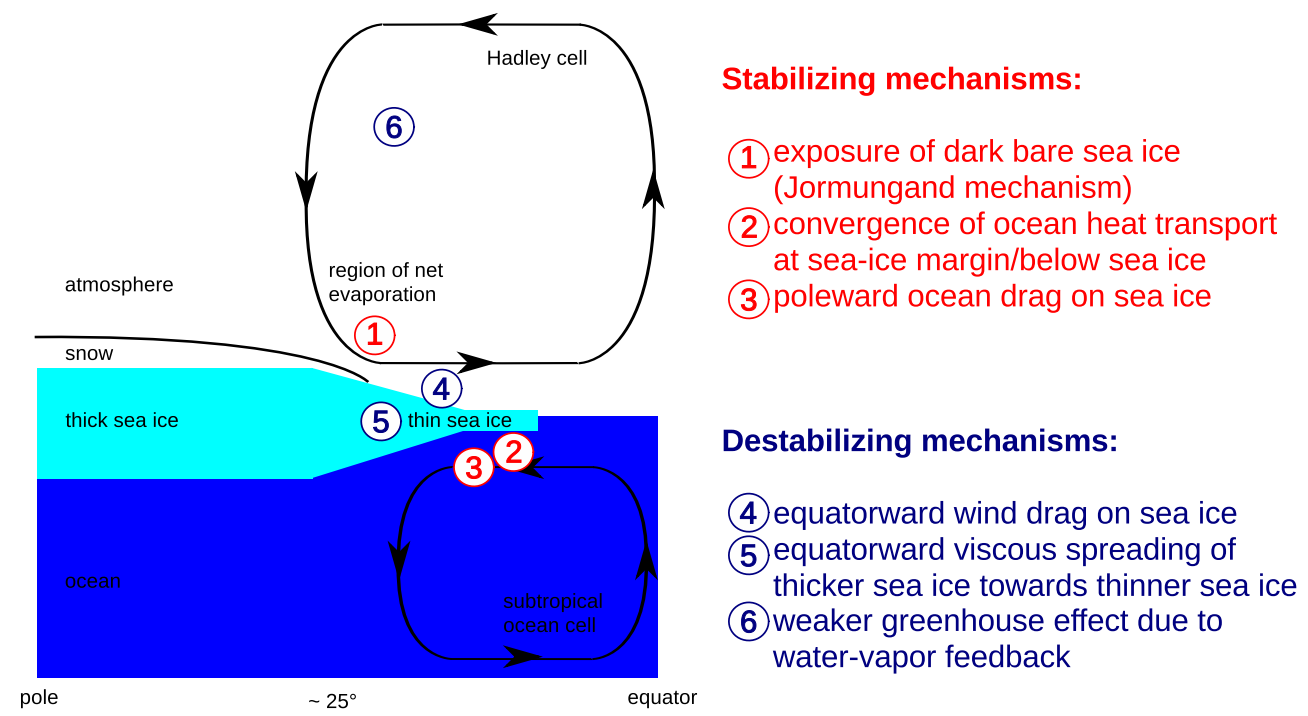

Fig. 13. Schematic illustration of mechanism that stabilize tropical sea-ice margins (red), thereby obstructing Snowball Earth initiation, or destabilize tropical sea-ice margins (blue), thereby promoting Snowball Earth initiation. See text for details. Ultimately, the Snowball Earth bifurcation is caused by the basic ice-albedo feedback (ice and snow reflect more shortwave radiation than land and water). As the figure is meant to illustrate mechanisms that are additional to the basic ice-albedo feedback, the latter is not included.

crucial to the easy Snowball initiation in ECHAM5/MPIOM. Since FOAM lacks sea-ice dynamics, this also helps to explain why Snowball initiation was so difficult in that model (Poulsen et al., 2002; Poulsen, 2003; Poulsen and Jacob, 2004), which is a result that had an outsized influence on the Snowball Earth debate in subsequent years (Kennedy et al., 2001; Lubick, 2002; Kerr, 2010). Finally, we note that we disabled sea-ice dynamics only in conjunction with a low bare sea-ice albedo of 0.45 because measurements favor such a low albedo. While we expect that sea-ice dynamics should promote Snowball initiation also for other bare sea-ice albedos, the quantitative effect of sea-ice dynamics may depend on the assumed sea-ice albedo.

Regarding the critical sea-ice cover, we find that decreasing the bare sea-ice albedo allows a more equatorward seaice margin while sea-ice dynamics destabilize the sea-ice margin. In ECHAM5/MPI-OM, sea-ice dynamics prevent stable sea-ice margins equatorward of $20^{\circ} \mathrm{N} / \mathrm{S}$ (Fig. 6), while stable sea-ice margins at $10^{\circ} \mathrm{N} / \mathrm{S}$ are possible without seaice dynamics. We attribute this destabilization mainly to the equatorward surface winds of the Hadley circulation and, to a lesser extent, viscous flow of sea ice. Besides this destabilizing mechanism through wind drag on sea ice, the Hadley circulation also leads to three stabilizing mechanisms as we schematically illustrate in Fig. 13. First, the Hadley circulation gives rise to the wind-driven subtropical ocean cells, which transport heat close to the sea-ice margin or even beyond (Fig. 7b of Yang et al., 2012a). Second, these ocean cells exert poleward drag on sea ice in the tropics. Third, the subsiding region of the Hadley cell in the subtropics leads to net evaporation there, which favors bare dark sea ice over snow-covered bright sea ice in low latitudes and reduces the ice-albedo feedback. The latter mechanism was first fully described in Abbot et al. (2011), who termed it the "Jormungand" mechanism. Here, we show that the Jormungand mechanism also operates in a coupled atmosphereocean general circulation model irrespective of the presence of continents, sea-ice dynamics, and ocean heat transport. However, sea-ice dynamics prevent states that show a clear separation of constantly bare sea ice in low latitudes and constantly snow-covered sea ice in higher latitudes.

With sea-ice dynamics disabled, we find a state that shares characteristics with the "Jormungand" states of Abbot et al. (2011). In this state, sea ice equatorward of $20^{\circ} \mathrm{N} / \mathrm{S}$ is bare year-round, and the resulting weakening in the ice-albedo feedback allows the sea-ice margin to stabilize in the tropics at $10^{\circ} \mathrm{N} / \mathrm{S}$. There is annual-mean accumulation of snow on tropical land in this state, suggesting that tropical land glaciers could grow. This state is therefore a soft Snowball Earth state.

There are no true Jormungand states and associated hysteresis and bifurcation in any of the three variants of ECHAM5/MPI-OM. Our simulations show that the absence of the Jormungand hysteresis in this model is not caused by either ocean heat transport or sea-ice dynamics. There are many potential reasons for the lack of Jormungand hysteresis, such as cloud behavior, particularly in the convergence zone of the strong Hadley circulation, differences in atmospheric dynamics among models, and continental configuration. Beyond these, the models' treatment of snow on sea ice likely plays a major role, in particular the snow thickness scale. This is because the snow thickness scale 
determines how fast bare sea ice turns into snow-covered sea ice (and vice-versa) and hence affects the contrast between the bare and snow-covered sea-ice albedo that leads to the Jormungand hysteresis. Specifics of the treatment of snow and sea ice may also explain why ECHAM5 in standalone mode showed Jormungand hysteresis in Abbot et al. (2011) while ECHAM5/MPI-OM does not. First, the standalone ECHAM5 model does not track snow on sea ice, which required Abbot et al. (2011) to prescribe the separation between bare and snow-covered sea ice at $20^{\circ} \mathrm{N} / \mathrm{S}$. ECHAM5/MPI-OM tracks snow on sea ice, so this is not necessary in the present study. Second, ECHAM5 in standalone mode does not allow partially sea-ice covered grid boxes while ECHAM5/MPI-OM does. It is also worth noting that ECHAM5/MPI-OM might exhibit "hidden" Jormungand states that are not accessible due to, for example, a particular combination of the model's bare sea-ice albedo and efficiency of meridional heat transport (Abbot et al., 2011). With these considerations in mind it is possible that coupled AOGCMs other than ECHAM5/MPI-OM exhibit Jormungand hysteresis, which would mean that the Jormungand hysteresis is model-dependent. For example, CCSM3 exhibits two stable states with 50 and $70 \%$ seaice cover, respectively, for the same $\mathrm{CO}_{2}$ and solar insolation (Yang et al., 2012a, Fig. 16b). Given that CCSM3 uses a strong albedo contrast between bare and snow-covered seaice, the bistability suggests that the state with $70 \%$ sea-ice cover might be a Jormungand state and that CCSM3 might exhibit Jormungand hysteresis. Future CCSM3 simulations are needed to test this suggestion.

The importance of sea-ice dynamics for Snowball Earth initiation calls for future work on sea-ice dynamics and their representation in climate models. The viscous flow of sea ice is parametrized and can be made more or less effective by changing the empirical parameters $P^{*}$ and $C^{*}$ (Eq. 3). Similarly, the wind and ocean drag coefficients influence how effectively equatorward surface winds destabilize and poleward ocean currents stabilize the sea-ice margin. As a result, the magnitude of the effect of sea-ice dynamics is tunable. Other models could therefore find a less pronounced role of sea-ice dynamics for Snowball Earth initiation. For example, CCSM3 exhibits stable tropical sea-ice margins despite active sea-ice dynamics and shows smaller sea-ice thickness tendencies than ECHAM5/MPI-OM (Yang et al., 2012a), which indicates that sea-ice dynamics are weaker in CCSM3 than in ECHAM5/MPI-OM. Moreover, in CCSM3, sea-ice dynamics lower the critical solar insolation by only less than $1 \%$ (Figs. 2 and 15a of Yang et al., 2012a). These differences suggest that sea-ice dynamics have a smaller effect on Snowball Earth initiation in CCSM3 than in ECHAM5/MPI-OM. They also suggest that the substantial differences in Snowball Earth initiation between the two models are primarily caused by differences in sea-ice dynamics and not sea-ice albedo. This clearly calls for future research on sea-ice dynamics to determine which model's simulations are most realistic.
Our results demonstrate that sea-ice dynamics need to be included in any modeling study concerned with Snowball Earth initiation, in particular in any study that aims to give a best estimate of the critical $\mathrm{CO}_{2}$ and sea-ice cover. Such studies also need to include the water-vapor feedback (Voigt and Marotzke, 2010; Yang et al., 2012a), clouds (Pierrehumbert et al., 2011), atmospheric dynamics (Abbot et al., 2011; Pierrehumbert et al., 2011), ocean dynamics (Poulsen et al., 2001), and a physically based treatment of sea-ice thermodynamics (Lewis et al., 2004). All these processes are needed to represent the three destabilizing and three stabilizing mechanisms illustrated in Fig. 13, four of which directly require the inclusion of sea-ice dynamics. Eventually, such models should also incorporate sea-ice glaciers.

\section{Conclusions}

We revisit Marinoan Snowball Earth initiation in the comprehensive atmosphere-ocean general circulation model ECHAM5/MPI-OM. All simulations use a low bare sea-ice albedo of 0.45 instead of the model's standard bare sea-ice albedo of 0.75 that we used in previous studies of Snowball initiation (Voigt et al., 2011; Voigt and Marotzke, 2010). Moreover we disable sea-ice dynamics and ocean heat transport to quantify the relative effect of these three factors on Snowball Earth initiation in this model. Figure 12 summarizes the estimates of the Snowball Earth bifurcation points. Our conclusions are as follows:

1. Regarding the critical $\mathrm{CO}_{2}$, a low bare sea-ice albedo and ocean heat transport make Snowball Earth initiation more difficult, while sea-ice dynamics facilitate Snowball Earth initiation. Sea-ice dynamics have a far larger effect on the critical $\mathrm{CO}_{2}$ than bare sea-ice albedo and ocean heat transport in this model.

2. Regarding the critical sea-ice cover, the effects of a low bare sea-ice albedo and sea-ice dynamics are similar in magnitude but opposite in sign. Ocean heat transport has no effect on the critical sea-ice cover in this model. A lower bare sea-ice albedo allows more equatorward sea-ice margins because sea ice tends to be bare near the sea-ice margin due to net evaporation and local melting of snow. Sea-ice dynamics destabilize the sea-ice margin due to equatorward transport of sea ice and snow.

3. When we disable sea-ice dynamics, we find a stable state with $85 \%$ sea-ice cover. This state has a tropical sea-ice margin at $10^{\circ} \mathrm{N} / \mathrm{S}$ and is enabled by the Jormungand mechanism described by Abbot et al. (2011): bare sea ice of low albedo is exposed when the sea-ice margin reaches the descent region of the Hadley circulation. However, while this state is a soft Snowball, it is not a true Jormungand state because there is no Jormungand bifurcation and associated hysteresis separating it from states with mid-latitude sea-ice margins. 
4. The Hadley circulation leads to three mechanisms that stabilize and to one mechanism that destabilizes tropical sea-ice margins. The Jormungand mechanism and subtropical ocean cells, through both ocean heat transport and ocean drag on sea ice, work against Snowball Earth initiation, while equatorward wind drag on sea ice promotes Snowball Earth initiation.

5. Model differences in the treatment of sea-ice dynamics can lead to large differences in Snowball Earth initiation. Future research is needed to improve the representation and constrain the strength of sea-ice dynamics.

Acknowledgements. We thank the three anonymous reviewers for their comments, and the editor Marie-France Loutre for help with evaluating the manuscript. We enjoyed discussions with Jochem Marotzke, Ray Pierrehumbert, Steffen Tietsche, Ian Eisenman, Arthur Miller and Uwe Mikolajewicz. We thank Helmuth Haak for advice on how to reduce the ocean model to one level, and Nils Fischer for the internal review at MPI-M. This work was supported by the Max Planck Society for the Advancement of Science. We acknowledge support from the German Research Foundation (DFG) program for the initiation and intensification of international collaboration. All simulations were performed at the German Climate Computing Center (DKRZ) in Hamburg, Germany.

Edited by: M.-F. Loutre

The service charges for this open access publication have been covered by the Max Planck Society.

\section{References}

Abbot, D. S. and Pierrehumbert, R. T.: Mudball: Surface dust and Snowball Earth deglaciation, J. Geophys. Res., 115, D03104, doi:10.1029/2009JD012007, 2010.

Abbot, D. S., Voigt, A., and Koll, D.: The Jormungand Global Climate State and Implications for Neoproterozoic Glaciations, J. Geophys. Res., 116, D18103, doi:10.1029/2011JD015927, 2011.

Brandt, R. E., Warren, S. G., Worby, A. P., and Grenfell, T. C.: Surface albedo of the antarctic sea ice zone, J. Climate, 18, 36063622, doi:10.1175/JCLI3489.1, 2005.

Budyko, M. I.: Effect of solar radiation variations on climate of Earth, Tellus, 21, 611-619, 1969.

Chandler, M. A. and Sohl, L. E.: Climate forcings and the initiation of low-latitude ice sheets during the Neoproterozoic Varanger glacial interval, J. Geophys. Res., 105, 20737-20756, 2000.

Evans, D. A. D.: Stratigraphic, geochronological, and paleomagnetic constraints upon the Neoproterozoic climatic paradox, Am. J. Sci., 300, 347-433, doi:10.2475/ajs.300.5.347, 2000.

Feltham, D. L.: Sea Ice Rheology, Ann. Rev. Fluid Mech., 40, 91112, doi:10.1146/annurev.fluid.40.111406.102151, 2008.

Ferreira, D., Marshall, J., and Rose, B.: Climate determinism revisited: multiple equilibria in a complex climate model, J. Climate, 24, 992-1012, doi:10.1175/2010JCLI3580.1, 2011.
Fortuin, J. P. F. and Kelder, H.: An ozone climatology based on ozonesonde and satellite measurements, J. Geophys. Res., 103, 31709-31734, doi:10.1029/1998JD200008, 1998.

Godderis, Y., Donnadieu, Y., Dessert, C., Dupre, B., Fluteau, F., Francois, L. M., Meert, J., Nedelec, A., and Ramstein, G.: Coupled modeling of global carbon cycle and climate in the Neoproterozoic: links between Rodinia breakup and major glaciations, Comptes Rendus Geosci., 339, 212-222, doi:10.1016/j.crte.2005.12.002, 2007.

Goodman, J. C. and Pierrehumbert, R. T.: Glacial flow of floating marine ice in "Snowball Earth", J. Geophys. Res., 108, 3308, doi:10.1029/2002JC001471, 2003.

Gough, D. O.: Solar interior structure and luminosity variations, Solar Physics, 74, 21-34, doi:10.1007/BF00151270, 1981.

Hibler, W. D.: Dynamic thermodynamic sea ice model, J. Phys. Oceanogr., 9, 815-846, 1979.

Hoffman, P. F., Kaufman, A. J., Halverson, G. P., and Schrag, D. P.: A Neoproterozoic snowball earth, Science, 281, 13421346, doi:10.1126/science.281.5381.1342, 1998.

Hyde, W. T., Crowley, T. J., Baum, S. K., and Peltier, W. R.: Neoproterozoic 'snowball Earth' simulations with a coupled climate/icesheet model, Nature, 405, 425-429, doi:10.1038/35013005, 2000.

Kennedy, M. J., Christie-Blick, N., and Sohl, L. E.: Are Proterozoic cap carbonates and isotopic excursions a record of gas hydrate destabilization following Earth's coldest intervals?, Geology, 29, 443-446, doi:10.1130/00917613(2001)029<0443:APCCAI>2.0.CO;2, 2001.

Kerr, R. A.: Snowball Earth has melted back to a profound wintry mix, Science, 327, 1186, doi:10.1126/science.327.5970.1186, 2010.

Kirschvink, J. L.: The Proterozoic Biosphere, chap. Late Proterozoic low-latitude global glaciation: The snowball Earth, 51-52, Cambridge University Press, New York, 1992.

Lewis, J. P., Weaver, A. J., Johnston, S. T., and Eby, M.: Neoproterozoic "snowball Earth": Dynamic sea ice over a quiescent ocean, Paleoceanography, 18, 1092, doi:10.1029/2003PA000926, 2003.

Lewis, J. P., Eby, M., Weaver, A. J., Johnston, S. T., and Jacob, R. L.: Global glaciation in the Neoproterozoic: Reconciling previous modelling results, Geophys. Res. Lett., 31, L08201, doi:10.1029/2004GL019725, 2004.

Lewis, J. P., Weaver, A. J., and Eby, M.: Snowball versus slushball Earth: Dynamic versus nondynamic sea ice?, J. Geophys. Res., 112, C11014, doi:10.1029/2006JC004037, 2007.

Liu, Y. and Peltier, W. R.: A carbon cycle coupled climate model of Neoproterozoic glaciation: Influence of continental configuration on the formation of a "soft snowball", J. Geophys. Res., 115, D17111, doi:10.1029/2009JD013082, 2010.

Losch, M., Menemenlis, D., Campin, J.-M., Heimbach, P., and Hill, C.: On the formulation of sea-ice models. Part 1: Effects of different solver implementations and parameterizations, Ocean Modell., 33, 129-144, doi:10.1016/j.ocemod.2009.12.008, 2010.

Lubick, N.: Palaeoclimatology: Snowball fights, Nature, 417, 12 13, doi:10.1038/417012a, 2002.

Macdonald, F. A., Schmitz, M. D., Crowley, J. L., Roots, C. F., Jones, D. S., Maloof, A. C., Strauss, J. V., Cohen, P. A., Johnston, D. T., and Schrag, D. P.: Calibrating the Cryogenian, Science, 327, 1241-1243, doi:10.1126/science.1183325, 2010. 
Marotzke, J. and Botzet, M.: Present-day and ice-covered equilibrium states in a comprehensive climate model, Geophys. Res. Lett., 34, L16704, doi:10.1029/2006GL028880, 2007.

Marsland, S. J., Haak, H., Jungclaus, J. H., Latif, M., and Roske, F.: The Max-Planck-Institute global ocean/sea ice model with orthogonal curvilinear coordinates, Ocean Modell., 5, 91-127, 2003.

McKay, C.: Thickness of tropical ice and photosynthesis on a snowball Earth, Geophys. Res. Lett., 27, 2153-2156, 2000.

Pierrehumbert, R., Abbot, D., Voigt, A., and Koll, D.: Climate of the Neoproterozoic, Annu. Rev. Earth Pl. Sc., 39, 417-460, doi:10.1146/annurev-earth-040809-152447, 2011.

Pollard, D. and Kasting, J. F.: Snowball Earth: A thin-ice solution with flowing sea glaciers, J. Geophys. Res., 110, C07010, doi:10.1029/2004JC002525, 2005.

Poulsen, C. J.: Absence of a runaway ice-albedo feedback in the Neoproterozoic, Geology, 31, 473-476, 2003.

Poulsen, C. J. and Jacob, R. L.: Factors that inhibit snowball Earth simulation, Paleoceanography, 19, PA4021, doi:10.1029/2004PA001056, 2004.

Poulsen, C. J., Pierrehumbert, R. T., and Jacob, R. L.: Impact of ocean dynamics on the simulation of the Neoproterozoic "Snowball Earth", Geophys. Res. Lett., 28, 1575-1578, doi:10.1029/2000GL012058, 2001.

Poulsen, C. J., Jacob, R. L., Pierrehumbert, R. T., and Huynh, T. T.: Testing paleogeographic controls on a Neoproterozoic snowball Earth, Geophys. Res. Lett., 29, 1515, doi:10.1029/2001GL014352, 2002.

Sellers, W. D.: A global climate model based on the energy balance of the Earth-atmosphere system, J. Appl. Meteorol., 8, 392-400, 1969.

Semtner, A. J.: Model for thermodynamic growth of sea ice in numerical investigations of climate, J. Phys. Oceanogr., 6, 379-389, 1976.
Tanré, D., Geleyn, J. F., and Slingo, J.: First results of the introduction of an advanced aerosol-radiation interaction in ECMWF low resolution global model, 133-177, Deepak Publishing, Hampton, VA, USA, 1984.

Trindade, R. I. and Macouin, M.: Palaeolatitude of glacial deposits and palaeogeography of Neoproterozoic ice ages, C. R. Geosci., 339, 200-211, doi:10.1016/j.crte.2007.02.006, 2007.

Tziperman, E., Halevy, I., Johnston, D. T., Knoll, A. H., and Schrag, D. P.: Biologically induced initiation of Neoproterozoic snowball-Earth events, Proc. Natl. Acad. Sci. USA, 108, 1509115096, doi:10.1073/pnas.1016361108, 2011.

Voigt, A. and Marotzke, J.: The transition from the present-day climate to a modern Snowball Earth, Clim. Dynam., 35, 887-905, doi:10.1007/s00382-009-0633-5, 2010.

Voigt, A., Abbot, D. S., Pierrehumbert, R. T., and Marotzke, J.: Initiation of a Marinoan Snowball Earth in a state-of-the-art atmosphere-ocean general circulation model, Clim. Past, 7, 249263, doi:10.5194/cp-7-249-2011, 2011.

Warren, S., Brandt, R. E., and McKay, C. P.: Snowball Earth: Ice thickness on the tropical ocean, J. Geophys. Res., 107, 1-17, 2002.

Yang, J., Peltier, W., and Hu, Y.: The initiation of modern "Soft Snowball" and "Hard Snowball" climates in CCSM3. Part I: the influences of solar luminosity, $\mathrm{CO}_{2}$ concentration, and the sea ice/snow albedo parameterization, J. Climate, 25, 2711-2736, doi:10.1175/JCLI-D-11-00189.1, 2012a.

Yang, J., Peltier, W. R., and Hu, Y.: The Initiation of modern "Soft Snowball" and "Hard Snowball" climates in CCSM3. Part II: climate dynamic feedbacks, J. Climate, 25, 2737-2754, doi:10.1175/JCLI-D-11-00190.1, 2012b.

Yang, J., Peltier, W. R., and Hu, Y.: The initiation of modern soft and hard Snowball Earth climates in CCSM4, Clim. Past, 8, 907-918, doi:10.5194/cp-8-907-2012, 2012c. 